\title{
PENERAPAN AKUNTANSI PERTANGGUNGJAWABAN SEBAGAI ALAT PENGENDALIAN BIAYA PADA PT. TELKOM CABANG LAMONGAN
}

\author{
Zuhrotun Nisak \\ Fakultas Ekonomi, Universitas Islam Lamongan
}

\begin{abstract}
ABSTRAK
Penelitian ini bertujuan untuk mengetahui bagai mana penerapan akuntansi pertanggungjawaban terhadap efisiensi pengendalian biaya pada PT.Telkom Lamongan. Data dari penelitian ini diperoleh dari kuesioner (premier), observasi dan wawancara langsung dengan pihak terkait. Sampel sebanyak 14 responden merupakan semua karyawan PT.Telkom Lamongan. Tehnik analisis yang digunakan adalah regresi berganda dan uji hipotesis dengan menggunakan uji $f$ dan uji t, yang sebelumnya telah dilakukan uji asumsi klasik terlebih dahulu. Hasil penelitian ini menunjukkan bahwa variabel akuntansi pertanggungjawaban yang terdiri atas struktur organisasi, perencanaan, pelaksanaan dan pelaporan secara simultan (uji $f$ ) berpengaruh signifikan terhadap pengendalian biaya. Uji parsial (uji t) diperoleh bahwa variabel struktur organisasi, perencanaan, pelaksanaan dan pelaporan secara parsial berpengaruh positif terhadap pengendalian biaya. Dari penelitian ini diperoleh nilai adjusted $R 2$ sebesar 0,712, hal tersebut berarti bahwa 21,2\% variabel dependen yaitu penendalian biaya dapat dijelaskan oleh variabel independennya yaitu struktur organisasi, perencanaan, pelaksanaan, dan pelaporan sisanya $28,8 \%$ dijelaskan oleh variabel-variabel lain diluar persamaan.
\end{abstract}

Kata kunci : akuntansi pertanggungjawaban, struktur organisasi, perencanaan, pelaksanaan, pelaporan pengendalian biaya.

\section{PENDAHULUAN}

Pada era globalisasi saat ini persaingan yang menjadi dalam dunia ekonomi sudah semakin ketat. Persaingan meningkat bukan saja dari sisi jumlahnya tetapi juga intensitas persaingannya. Persaingan semakin tajam dengan berubahnya karakter lingkungan perusahaan. Adanya perubahan atas lingkungan perusahaan tersebut memaksa perusahaan untuk mengubah pola pikir yang lama dan menyesuaikanya dengan keadaan dan kebutuhan saat ini. Perusaan dituntut untuk mampu mengidentifikasi, mengelola , memperbaiki proses bisnis yang penting. Hal itu agar perusahaan memperoleh keunggulan kompetitif dan dapat bertahan ditengah persaingan ketat dunia usaha. 
Persaingan usaha pada layanan jasa telekomunikasi seluler juga mengalami hal demikian, ada beberapa alasan mengapa sampai persaingan usaha pada jasa layanan komunikasi seluler mengalami persaingan yang cukup ketat di bandingkan beberapa tahun yang lalu dimana persaingan antar penyedia layanan komuniksi hanya didominasi oleh beberap perusaan tertentu. Dengan semakin banyaknya penguna telepon seluler dikalangan masyarakat, ini menjadi kesempatan bagi perusahaanpeusahaan lain untuk bersaing dalam bisnis penyedia dalam layanan komunikasi seluler di Indonesia, dan menjadi peta persaingan usaha jasa layanan komunikasi semakin ketat.

Berdasarkan uraian latar belakang di atas, masalah pokok dari penelitian ini adalah: (1) Apakah penerapan stuktur organisasi akuntansi pertanggungjawaban dengan menetapkan wewenang secara tegas dapat berpengaruh pada pengendalian biaya. (2) Apakah sistem perencanaan/anggaran pada akuntansi pertanggungjawaban berpengaruh pada pengendalian biaya. (3) Apakah sistem pelaksanaan/anggaran pada akuntansi pertanggungjawaban berpengaruh pada pengendalian biaya. (4) Apakah sistem pelaporan/anggaran pada akuntansi pertanggungjawaban berpengaruh pada pengendalian biaya.

\section{TINJAUAN PUSTAKA}

\subsection{Akuntansi Pertanggungjawaban}

Menurut Bidang

(2013:30)

Akuntansi pertanggungjawaban pada hakekatnya adalah salah satu aspek dari system pengendalian manajemen yang berkaitan dengan pemberian informasi untuk memudahkan manajemen dalam mengendalikan kegiatan operasional perusahaan termasuk didalamnya dalam mengukur kinerja manajemen. Metode pengumpulan dan pemusatan wewenang dalam akuntansi manajemen dikenal dengan akuntansi pertanggungjawaban (Simamora, 2002).

\subsection{Pengendalian Manajemen}

Pengendalian manajemen adalah suatu proses dimana manajemen menjamin bahwa organisasi telah melaksanakan strategi dengan efektif dan efesien. Dalam hal ini efektif diukur berdasarkan kaitan antara output pusat pertanggungjawaban dengan tujuan atau target yang ditetapkan, sedangkan efesien adalah perbandingan antar output dengan input pusat pertanggungjawaban (Bidang, 2013:31). 
Biasanya dalam suatu perusahaan kecil atasan mengawasi kegiatan rutin perusahaan melalui kontak tatap muka dengan karyawanya, namun ketik perusahaan mulai mengalami perkembangan, tanggung jawab pimpinan semakin besar sehinggan diperlukan wewenang dan tanggung jawab kepada bawahanya. Dalam pendelegasian suatu wewenag dan tanggung jawab bukan berarti bahwa tanggung jawab bukan berarti bahwa tanggung jawab pimpinan menjadi kurang, tetapi tanggung jawab yang dilimpahkan tersebut tetap dikendalikan oleh pimpinan sebagai pemberi wewenang. Dengan adanya pendelegasian wewenang kepada setiap tingkat manajer dalam perusahaan, menuntut manajer masing-masing unit untuk bertanggung jawab kepada manajer yang lebih tinggi serta dapat mendorong manajer agar bekerja lebih baik. Untuk menilai pertanggungjawaban wewenang yang diberikan kepada bawahan, dibutuhkan suatu metode akuntansi pertanggungjawaban berkaitan dengan pengelompokan dan pemusatan wewenang.

\section{METODOLOGI PENELITIAN}

Dalam penelitian ini dibutuhkan data yang sesuai dengan masalah- masalah yang ada serta tujuan dari penelitian, sehingga data yang dikumpulkan dapat dilakukan analisis dan ditarik kesimpulan, untuk itu diperlukan metode penelitian yang tepat dan akurat. Dalam penelitian ini digunakan pendekatan kuantitatif. Dimana data kuesioner dan hasil wawancara yang diperoleh selama penelitian lakukan, diolah , dianalisis, dan diproses lebih lanjut dengan menggunakan penerapan akuntasi pertanggungjawaban yang telah dipelajari guna memenuhi tujuan penelitian.

\section{HASIL PENELITIAN DAN PEMBAHASAN}

\subsection{Uji Validitas dan Reliabilitas}

\section{Instrumen}

Kuesioner dikatakan valid apabila pernyataan yang terdapat didalam kuesioner mampu mengungkapkan sesuatu yang ukur oleh angket tersebut. Hasil uji validitas melalui proses program SPSS dengan menggunakan rumus Pearson (korelasi product moment) terhadap instrumen penelitian dapat diketahui bahwa seluruh pertanyaan valid. Sedangkan suatu kuesioner dikatakan reliabel jika nilai Alpha Cronbach di atas 0,60 (Ghozali, 
2009). Hasil koefisien Alpha Cronbach untuk semua variabel nilainya lebih dari 0,60 , sehingga dapat disimpulkan bahwa instrumen penelitian ini reliabel.

\subsection{Analisis Regresi Akuntansi Per- tanggungjawaban terhadap Pe- ngendalian Biaya}

Berikut ini akan diuraikan hasil analisis regresi untuk melihat pengaruh masing-masing variabel independen terhadap variabel dependen sebagai berikut:

a. Variabel Struktur Organisasi (X1)

Nilai $t_{\text {hitung }}$ untuk variabel ini sebesar 3,133 . Sementara itu nilai pada $t_{\text {table }}$ distribusi 5\% sebesar 2,26216. Maka $t_{\text {hitung }}(-3,133)>t_{\text {tabel }}(2,26216)$ dan nilai signifikan $(0,012<0,050)$ artinya variabel struktur organisasi $\left(\mathrm{X}_{1}\right)$ berpengaruh negative dan signifikan terhadap pengendalian biaya (Y) maka untuk $\mathrm{H}_{1}$ dapat diterima atau $\mathrm{H}_{0}$ di tolak.

b. Variabel perencanaan/Anggaran (X2)

Nilai $t_{\text {hiung }}$ untuk variabel ini sebesar 1,612. Sementara itu nilai pada table distribusi 5\% sebesar 2,26216. Maka $t_{\text {hitung }}(1,612)>t_{\text {tabel }}(2,26216)$ dan nilai tidak signifikan $(0,141>0,050)$ artinya variabel perencanaan anggaran $\left(\mathrm{X}_{2}\right)$ berpengaruh tidak berpengaruh positif dan tidak signifikan terhadap alat pengendalian biaya (Y) maka untuk $\mathrm{H}_{2}$ tidak diterima atau $\mathrm{H}_{0}$ diterima.

c. Variabel pelaksanaan/Pengendalian (X3)

Nilai $t_{\text {hitung }}$ untuk variabel ini sebesar 3,782. Sementara itu nilai pada tabel distribusi 5\% sebesar 2,26216. Maka $t_{\text {hitung }}(3,782)>t_{\text {tabel }}(2,26216)$ dan nilai signifikan $(0,004<0,050)$ artinya variabel pelaksanaan/ pengendalian $\left(X_{3}\right)$ berpengaruh positif dan signifikan terhadap pengndalian biaya (Y) maka untuk $\mathrm{H}_{3}$ dapat diterima atau $\mathrm{H}_{\mathrm{O}}$ ditolak.

d. Variabel Pelaporan (X4)

Nilai $t_{\text {hitung }}$ untuk variabel ini sebesar 3,328. Sementara itu nilai pada table distribusi 5\% sebesar 2,26216. Maka thitung $(3,328)>t_{\text {tabel }}(2,26216)$ dan nilai signifikan $(0,009<050)$ artinya variabel pelaksanaan/pengendalian biaya $\left(\mathrm{X}_{3}\right)$ berpengaruh posistif dan signifikan terhadap alat pengendalian biaya (Y) maka untuk $\mathrm{H}_{1}$ dapat diterima atai $\mathrm{H}_{\mathrm{O}}$ ditolak.

Dengan hasil diatas, menunjukkan bahwa hipotesis yang ada dapat diterima dan $\mathrm{X}_{2}$ ditolak dikarenakan kurangnya penencanaan/anggaran di PT.Telkom Lamongan oleh penguji ini. Adapun 
rumusan regresi berganda yang digunakan sebagai berikut:

$$
\begin{aligned}
\mathrm{Y}= & -24,539-3115 \mathrm{X}_{1}+1,153 \mathrm{X}_{2}+ \\
& 2,236 \mathrm{X}_{3}+1,197 \mathrm{X}_{4}
\end{aligned}
$$

Berdasarkan dari hasil penelitian dari table uji hipotesis menunjukan hubungan (R) penerapan akuntansi pertanggungjawaban sebesar 0,895 atau $89,5 \%$ yang menunjukkan hubungan (korelasi) yang cukup baik dengan tingkatan tertinggi bahwa semakin nilainya mendekati 1 maka semakin tinggi pula hubunganya, dan di $\mathrm{R}$ squeare $\left(\mathrm{R}^{2}\right)$ dikatakan bahwa besaranya R Squeare (koefisiensi determinasi yang telah disesuaikan) adalah 0,801. Nilai ini menjukan bahwa $80,1 \%$ pendalian biaya dapat dijelaskan oleh variasi dari variabel dependen yaitu penerapan akuntansi pertanggungjawaban, sedangkan sisanya $19.9 \%$ dipengaruhi oleh variabel-variabel lain yang tidak diteliti dalam penelitian ini. Dan melalui uji $\mathrm{F}$ juga dapat dilihat bahwa variabel partisipasi dan inovasi memiliki pengaruh simultan yang positif dan signifikan karena $\mathrm{F}$ hitung $\mathrm{F}$ table yaitu $9,054>3,63$.

a. Hipotesis $\left(\mathrm{X}_{1}\right)$ Dengan hasil uji $\mathrm{t}$ struktur organisasi disimpulkan bahwa variabel ini dapat memberikan pengaruh positif dan signifikan terhadap pengendalian biaya, memiliki $\mathrm{T}$ hitung $(3,133)>\mathrm{t}$ table (2,26216) dan signifikan $(0,020<0,051)$, dengan hasil ini menunjukan bahwa hiotesis pertama dapat diterima terhadap pengendalian biaya pada PT.Telkom.

b. Hipotesis (X2) kemudian pada variabel perencanaan/anggaran disimpulkan bahwa variabel ini tidak memberikan pengaruh posistif dan signifikan terhadap pengendalian biaya dikarenakan rerencanaan/anggaran kurang terrealisasi. Variabel ini memiliki nilai $\mathrm{T}$ hitung $(1,612>\mathrm{t}$ table $(2,26216)$ dan nilai tidak signifikan $(0,141>0,050)$, hasil ini menjukan bahwa hipotesis ke dua dapat tidak diterima terhadap pengendalian biaya pada PT.Telkom.

c. Hipotesis (X3) variabel pelaksanaan/pengendalian disimpulkan bahwa variabel ini memberikan pengaruh positif dan signifikan dengan nilai $\mathrm{T}$ hitung $(3,782)>\mathrm{T}$ table (2.26216) dan signifikan $(0,004<(0,050)$, dari hasil ini meunjukkan bahwa hipotesis ke tiga dapat diterima 
terhadap pengendalian biaya pada PT.Telkom.

d. Hipotesis (X4) pada variabel pelaporan disimpulkan bahwa variabel ini juga dapat memberikan pengaruh posistif dan signifikan terhadap pengendalian biaya, dengan memiliki T hitung $(3,238)>$ t table $(2,26216)$ dan nilai signifikan $(0,008<0,050)$, dan menjukan hipotesis ke empat dapat diterima terhadap pengendalian biaya pada PT.Telkom.

Dengan demikian hasil penelitian ini menyatakan bahwa penerapan akuntansi pertanggungjawaban sebagai alat pengendalian biaya memiliki pengaruh positif dan signifikan dan ada pula yang tidak signifikan dikarenakan perencanaan atau anggaran kurang terrealisasi, hal ini menjukkan bahwa peneraan akuntansi pertanggungjawaban di PT.Telkom Lamongan cukup baik dan dapat meningkatkan efisiensi biaya pada perusahaan.

\section{PENUTUP}

\subsection{Simpulan}

Berdasarkan analisis dan pembahasan yang telah dikemukakan, maka sebagai kesimpulan dan hasil penelitian diperoleh hasil sebagai berikut:

a. PT.Telkom Lamongan telah menerapkan system akuntansi pertanggungjawaban dalam organisasinya dengan cara membagi-bagi pusat pertanggung-jawaban dapat dilihat dari hasil analisis mengenai variabel struktur organisasi, berpengaruh positif dan signifikan terhadap pengendalian biaya.

b. Perencanaan/anggaran yang dibuat PT.Telkom Lamongan, telah disusun sesuai dengan tingkat manajemen dalam organisasi. Tiap manajer mengajukan rancangan anggaran biaya-biaya yang berada dibawah tanggung jawabnya masing-masing. Dari hasil analisis mengenai variabel perncanaan/anggaran menunjukkan bahwa variabel ini tidak berpengaruh positif dan tidak signifikan terhadap pengendalian biaya dikarenakan kurangnya percanaan/anggaran.

c. Informasi akuntansi pertanggungjawaban telah menjadi alat control pada PT.Telkom untuk melaksanakan/menngendalikan aktivitasnya, dapat dilihat dari hasil analisis mengenai variabel pelaksana- 
an/pengendalian yang berpengaruh posistif terhadap pengendalian biaya.

d. Sistem pelaporan yang diterapkan pada PT.Telkom Lamongan telah dilaksanakan sesuai dengan system akuntansi pertanggungjawaban dengan menetapkan antara realisasi dengan anggaran dan mengevaluasi sebab-sebab terjadinya perbedaan. Dari hasil analisis mengenai variabel pelaporan menunjukkan bahwa variabel tersebut berpengaruh positif dan signifikan terhadap alat pengendali biaya.

\subsection{Saran}

Akuntansi pertanggungjawaban pada PT.Telkom Lamongan pada dasarnya telah diterapkan dan dilaksanakan dengan baik. Begitu juga dalam pelaksanaan pengendalian biaya, perusahaan telah melakukan pengendalian dengan cukup baik. Namun masih ditemukan kelemahan dalam perusahaan. Oleh karena itu, penulis mecoba memberikan saran, adapun sasaran yang bias dijadikan masukan untuk perusahaan.

a. Setiap penanggungjawab biaya sebaiknya memuat laporan pertanggungjawaban dalam mekanisme pengendalian anggaran biaya. Dengan demikian akan tampak dengan jelas biaya-biaya apa saja yang termasuk dalam kendali seorang manajer.

b. Manajer sebaiknya melakukan analisis dan koreksi terhadap penyimpangan yang tidak menguntungkan kemudian mengajukan rekomendasi menanggapi penyimpangan materil yang terjadi.

c. Sebaiknya dibuat kebijakan yang tegas mengenai hukum kepada manajer yang kjinerjanya kurang baik. Dengan asumsi bahwa tidak tercapinya target biaya yang ditentukan merupakan kelalaian manajer dan kelalaian dalam menjalankan aktivitas perusahaan.

d. Apabila ada kegiatan baru yang muncul dan tidak diangarkan sebelumnya sebaiknya diadakan rapat untuk melakukan revisi terhadap anggaran. Hal ini perlu dilakukan karena sangat mempengaruhi kinerja manajer yang bersangkutan dan mempunyai dampak negative terhadap perusahaan.

Penelitian ini tidak terlepas dari beberapa keterbatasan antara lain: 
a. Hasil penelitian ini hanya dapat diajadikan analisis obyek penelitiian yang terbatas yaitu karyawan PT.Telkom Lamongan, sehingga memungkinkan adanya perbedaan hasil penelitian dan penarikan kesimpulan apabila peneliti dilakukan pada obyek dan lokasi penelitian yang berdeda.

b. Penarikan kesimpulan yang dimbil hanya berdasarkan pada data yang dikumpulkan melalui penggunaan instrument secara tertulis, sehingga peneliti tidak dapat mengontrol kemungkinan terjadinya bias akibat perbedaan situasi dan kondisi responden saat pengisian kuesioner. Selain itu, kemungkinan terjadinya interprestasi atau penyataan kuesioner dapat terjadinya bias dalam pengisian kuesioner.

\section{DAFTAR PUSTAKA}

Bidang, Handrinal. 2013. Penerapan Kuntansi pertanggungjawaban sebagai alat pengendalian biaya pada PT.Telkomsel regional Sulawesi dan papua. Universitas Hasanudin Makasar. Tidak diterbitkan
Ghozali, Imam. 2009. Ekonometrial: Teori Konsep dan Aplikasi dengan SPSS 17. Semarang : Badan Penerbit Universitas Diponegoro.

Simamora, Henry. 2002. Akuntansi Manajemen. Edisi ke-11. UPP AMP YKPN. 